\title{
Investigation of biodegradable coatings produced from three different protein sources for white cheese packaging
}

\author{
Üç farklı protein kaynağından beyaz peynir ambalajı olarak üretilen biyobozunur \\ kaplamaların incelenmesi
}

\author{
Gözde KAYA ÖZKÖK: ID , Zeynep TACER CABA ${ }^{1}$ iD
}

${ }^{1}$ Istanbul Aydin University, Engineering Faculty, Department of Food Engineering, 34295 Istanbul, Turkey

\section{To cite this article:}

Kaya-Özkök, G. \& Tacer-Caba, Z. (2019). Investigation of biodegradable coatings produced from three different protein sources for white cheese packaging. Harran Tarım ve Gida Bilimleri Dergisi, 23(1): 1-12. DOI:10.29050/ha rranziraat.4 08889

Address for Correspondence: Zeynep TACER CABA e-mail:

zeyneptcaba@gmail.com

Received Date: 22.03.2018

Accepted Date: 18.01.2019

(c) Copyright 2018 by Harran University Faculty of Agriculture. Available on-line at www.dergipark.gov.tr/harranziraat

\section{ABSTRACT}

Biodegradable films and coatings; attract an increasing interest recently being natural and environmentally friendly alternatives to synthetic food packaging materials. Some terms such as "renewable, food preservative, thin layers, food life extender" might be used for defining these materials. Proteins have a high potential to be used in food packaging. This study aimed to compare the performances of three different protein sources (whey protein, soy protein and gluten) as biodegradable coatings for cheese samples. Effect of red grape juice addition into coating solutions was also investigated. In this study, $15 \mathrm{~g}$ coating solution is used to coat 3-3.5 g cheese slice in each treatment. The results of the study revealed that the coatings produced were elastic, adhesive, transparent and durable. Among the different coatings, gluten had a more stretch and adhesive structure. Soy protein and whey protein coatings inhibited the moisture loss in cheese samples slightly more than gluten films. Grape juice addition to soy and whey protein coatings made the cheese samples more resistant to microbial growth. The whey protein coating was the thickest among them. The results depicted that, whey protein coating with grape juice is the most promising application, by providing lower microbiological load and moisture loss in cheese samples, and depicting lower color and moderate solubility. In future studies, combined usage of fruit sources with protein coatings might be helpful to improve the cheese quality in biodegradabl e packages.

Key Words: Biodegradable, Coating, Gluten, Soy protein, Whey protein

öz

Biyobozunur filmler ve kaplamalar sentetik gıda ambalaj malzemelerine alternatif, doğal ve çevre dostu malzemeler olarak son yıllarda giderek artan bir ilgi görmektedir. Bu malzemelerin tanımlanmasında "yenilenebilir, gıda koruyucu, ince tabaka, gıdanın raf ömrünü uzatıcı" gibi terimler kullanmak mümkündür. Proteinlerin gıda a mbalajlamada kullanılmak üzere önemli bir potansiyele sahiptir. Bu çalışmada üç farklı protein kaynağının (peynir altı suyu proteini, soya proteini ve gluten) peynir örnekleri için biyobozunur kaplama olarak davranışlarının karşılaştırılması amaçlanmıştır. Çalışmada ayrıca kaplamalara eklenen üzüm suyunun etkileri de incelenmiştir. Bu çalışmada, her bir tür protein çözeltisi (15 g), 3-3.5 g peynir diliminin kaplanmasında kullanılmıştır. Çalışma tüm kaplamaların esnek, yapışkan, transparan ve dayanıklı olduklarını göstermiştir. Farklı kaplamalar arasında, glutenin daha esnek ve daha yapışkan bir yapıya sahip olduğu gözlenmiştir. Soya proteini ve peynir altı suyu proteini içeren kaplamalar peynir örneklerindeki nem kaybını gluten kaplamalara göre biraz daha fazla engelleyebilmişlerdir. Kaplama çözeltilerine üzüm suyu eklenmesi peynir örneklerini mikrobiyal gelişmeye karşı daha dayanıklı hale getirmiştir. Bütün materyaller arasında peynir altı suyu proteini içeren kaplamalaren kalın olanlardır Çalışmada elde edilen sonuçlara göre, üzüm suyu eklenen peynir altı suyu proteini kaplamaları, peynir örneklerinde daha düşük mikrobiyal yük ve nem kaybı sağlamaları, daha az renklilik ve kabul edilebilir düzeydeki çözünürlük düzeyleri ile en öne çıkan uygulama olmuştur. Gelecekte yapılacak çalışmalarda, meyve kaynaklarının protein kaplamalarile birlikte kullanımının biyobozunur ambalaja sahip peynirlerin kalitesinin geliştirilmesinde daha faydalı ola cağı düşünülmektedir.

Anahtar Kelimeler: Biyobozunur, Kaplama, Gluten, Soya proteini, Peynir altı suyu proteini 


\section{Introduction}

Current increase in environmental consciousness of consumers has directed research more on packaging as the highest amount of solid waste produced by human is package based. Nowadays, biodegradable films packaging concept has raised due to their advantages to nature and wide range of potential application for food preservation and food protection.

Films and coatings are terms that are sometimes used as synonyms, although they represent different concepts. Film may be defined as "a thin layer of material that can be used as a cover or wrap" forming a stand-alone material; while coatings, being available in liquid form, are directly formed on the surface of the food product they are intended to be used with (Gennadios, 2002; Guimaraes et al., 2018; Costa et al., 2018).

Biodegradable films and coatings are most commonly obtained from polysaccharide or protein sources. Coatings from proteins can be obtained inexpensively and simply from either animals (such as keratin, collagen, gelatin, casein and whey proteins etc.) or plants (maize, wheat, soy, peanut etc.) are widely used (Akbari et al., 2007). Their particular mechanical and oxygen properties have been found to be superior in comparison to some polysaccharide and oil based counterparts (Khwaldia et al., 2004). Moreover, their high water vapor permeability also seems as an advantage to delay the drying of food materials, although this hydrophilic properties make them bad barriers to water at the same time (Guilbert, 1986).

Whey protein is one of the by-products of cheese production process and is made up of lactose, minerals and some of the vitamins, milk proteins and milk in small quantities. Whey proteins consist of $20 \%$ of milk proteins such as $\alpha$ lactalbumin, $\beta$-lactoglobulin, bovine serum albumin, immunoglobulins and proteosepeptones, which are soluble at $\mathrm{pH} 4.6$ (Kinsella and Whitehead, 1989). However, whey protein- based coatings, although having a high biological value, seem to have a low moisture barrier function and high water vapor permeability in comparison to carbohydrate and lipid-based films. Therefore, it is generally recommended to use plasticizer materials such as glycerine, sorbitol, polyethylene glycol etc. to increase moisture barrier properties (McHugh et al., 1994; Gounga et al., 2007)). These plasticizers are also significant for decreasing the brittleness and increasing the flexibility of the whey protein films (Ozdemir and Floros, 2008).

Soy proteins are significant alternatives of plant derived protein films/coatings. They have a high content of protein (38\% -44\%), also is oflavones, omega-3-fatty acids and dietary fiber (Riaz, 2001; Liu, 2004). Soy protein isolates having at least $90 \%$ protein content are often used as raw materials in the biodegradable films. Their biodegradability rates are high, beside their functional properties such as stickiness, water and oil retention, texturing ability and fibrous structure make them as favorable alternatives for biodegradable packaging. Although they exhibit water retention properties; soy protein coatings are required to be enriched with auxiliary materials particularly in very humid conditions (Varzokas and Tzia, 2016). Soy protein sources have been used together with other materials such as stearic acid and pullulan ( $\alpha$-glucan) to increase the storage process of the kiwis (Temiz and Yeşilsu, 2006); apple pectin (Mariniello et al., 2003) and mozzarella cheese (Zhong et al., 2018).

Wheat gluten is a significant component of wheat. Moreover, it is also an important side product during the production of wheat starch. Wheat gluten coatings have strong mechanical properties and they are transparent, homogeneous and hydrophobic. They are commonly used in composite films by adding oil or cellulose to their structures, although they still need plasticizers for increasing their plasticity and surface area (Gontard and Guillaume, 2010; Pochat-Bohatier et al., 2005). A study on the glycerol-plasticized gluten films, highlighted the importance of different temperatures and relative 
humidity values on mechanical and physical properties of the films produced (Kayserilioğlu et al., 2003). Generally, drying temperature has been reported to affect the mechanical and physical properties of wheat gluten-based films more than relative humidity changes (Kayserilioğlu et al., 2003).

Cheese may be defined as a food matrix consisting mainly of casein, fat, and water having a relatively short shelf life. It is widely consumed around the world for ages and represents an ideal food model system to study the coating process having a smooth surface, uniform texture, and regular shape (Zhong et al., 2014). The flavor formation in cheese, in parallel manner with other dairy products, is related to the activity of lactic acid bacteria synthesizing the intracellular enzymes during fermentation, to a lesser extent molds and yeasts (Karagozlu and Karagozlu, 2016). Studies on shelf-life extension of cheese have been achieved by using some chemical preservatives such as synthetic antioxidants and antibacterial agents. However, increasing consumer awareness toward the negative health consequences of synthetic additives also commonly arises as a barrier for acceptance of these products nowadays (Gurdian et al., 2017). Therefore, investigations about plant extracts, as potential natural food additives, have attracted increasing attention (Gutierrez et al. 2009; Akcan et al., 2017). To our knowledge, on the other hand, only a few or no previous attempts in literature have been found to evaluate the effects of fruit juices addition in protein based coating solutions.

Ezine cheese is a unique type of traditional Turkish white cheese that is produced by using milk from goat, sheep and/or cow. It is brined (pickled), and has a characteristic taste and aroma (Karagul-Yuceer et al., 2007). Very recent studies in literature focused on different biodegradable coatings to increase the shelf lives of various cheese verities such as Prato cheese (de Lima Marques et al., 2017); queso blanco cheese (Gurdian et al., 2017).

This study aimed to compare the performances of three different protein sources as biodegradable food packaging alternatives for Ezine cheese samples. Furthermore, effect of red grape juice addition into the coating solutions was also investigated.

\section{Materials and Methods}

\section{Materials}

Commercial protein powders of whey protein (Hardline, Turkey) ( 95\% w/w protein), soy protein (Alfasol, Turkey) ( $70 \% \mathrm{w} / \mathrm{w}$ protein) and wheat gluten protein (Alfasol, Turkey) ( $75 \% \mathrm{w} / \mathrm{w}$ protein) were utilized. Cardinal variety red table grapes (Vitis vinifera L.) (Istanbul, Turkey) were supplied from a local market and blended with a blender (Waring, USA). The grape puree was filtered with filter paper and grape juice was obtained as filtrate. White cheese samples were Ezine type (Tahsildaroğlu, Turkey).

\section{Chemicals}

Main chemicals used in the study, such as sodium hydroxide $(\mathrm{NaOH})$, ammonium hydroxide $\left(\mathrm{NH}_{4} \mathrm{OH}\right)$, ethanol $\left(\mathrm{C}_{2} \mathrm{H}_{6} \mathrm{O}\right)$, sodium azide $\left(\mathrm{NaN}_{3}\right)$, hydrochloric acid $(\mathrm{HCl})$ and 2,2-Diphenyl-1picrylhydrazyl (DPPH) were all analytical reagent grade and purchased from Sigma-Aldrich (Germany). Glycerol (DuzeyLab, Turkey) was the used for elasticity.

\section{Preparation of coating solutions}

Films composed of different portions of protein sources, glycerol, water and bases necessary and were formed by casting the final solution (15 g) into 9-cm diameter Petri dishes on $3 \mathrm{~g}$ cheese slices. The coating solutions on cheese samples were dried for 24 hours at room temperature. Details for production methods of different types of coatings were given below.

\section{Whey protein coating}

The whey protein film was prepared by modifying a previous method (Kaya and Kaya, 2000). Distilled water $(200 \mathrm{ml})$ was added into whey protein $(16 \mathrm{~g})$ and heated to $90^{\circ} \mathrm{C}$. Finally, 
the glycerol $(8 \mathrm{ml})$ was added into mixture as the plasticizer and final mixture was centrifuged at $3000 \mathrm{~g}$ for 10 minutes (Heittich-Rotofix, Germany). The separated supernatant was used as the coating solution.

\section{Soy protein coating}

Soy protein based film forming method described by Nie et al. (2015) was modified. Soy protein of $14 \mathrm{~g}$ was weighed and $200 \mathrm{ml}$ distilled water was added and homogenized. The $\mathrm{pH}$ of the mixture was adjusted to 11 by $\mathrm{NaOH}(2 \mathrm{M})$. The mixture was heated to $70{ }^{\circ} \mathrm{C}$. When the temperature was cooled to room temperature, 6 $\mathrm{ml}$ of glycerol was added into mixture as the plasticizer and the mixture was centrifuged at $3000 \mathrm{~g}$ for 10 minutes. Separated clear supernatant was used as the coating solution.

\section{Wheat gluten coating}

Wheat gluten based films were prepared by slightly modified method of Gontard et al. (1993) and Tanada-Palmu et al. (2004). $15 \mathrm{~g}$ of wheat gluten protein was weighed and mixed rapidly with $90 \mathrm{ml}$ of ethanol. Then $200 \mathrm{ml}$ of distilled water was added. To adjust the $\mathrm{pH}$ value to $10 ; 10$ $\mathrm{ml}$ of $\mathrm{NH}_{4} \mathrm{OH}(6 \mathrm{~N})$ was added into mixture and then heated to $75^{\circ} \mathrm{C}$. Glycerol $(4.5 \mathrm{ml})$ was added. The mixture was centrifuged at $3000 \mathrm{~g}$ for 10 minutes and clear supernatant was collected to be used as coating solution.

\section{Preparation of red grape juice and addition into} coating solutions

For the treatments with red grape juice, red grapes were squeezed and filtered through filter paper. In grape juice added films, the same procedures explained above were applied until heating steps; and then squeezed red grape filtrates having dry matter content of $22 \%$ (1.5 $\mathrm{ml})$, were added into all three different films before the glycerol addition steps.

\section{Microbiological growth on coated cheese samples}

Total yeast and mold populations and total coliform bacteria were evaluated on coated cheese samples on days 1, 3 and 5 after coating applications. Yeast Extract Glucose Chloramphenicol (YGC) (Merck, Germany) was used for yeast and mold count and Violet Red Bile Agar (VRBA) (Merck, Germany) for coliform bacterial count. Biodegradable film coated cheese samples were homogenized for 1 minute in a stomacher by adding $9 \mathrm{ml}$ sterile peptone water to $1 \mathrm{~g}$ sample. Serial dilutions of $\left(10^{-1}-10^{-5}\right)$ were plated $(0.1 \mathrm{ml})$ in triplicates using spread plate method. For yeast and mold count, about 15-20 $\mathrm{ml}$ of $\mathrm{YGC}$ agar solution (at $45-50^{\circ} \mathrm{C}$ ) was poured onto sterile petri plates kept until the solution cooled down to room temperature (about $25{ }^{\circ} \mathrm{C}$ ) (in sterile conditions) (ISO 7954, 1988). For coliform bacterial count, serial dilutions of the samples $(0.1 \mathrm{ml})$ were plated onto sterilized VRBA agar. Colony counting were made after 24-48 hours of incubation at $37^{\circ} \mathrm{C}$.

All microbiological results were given as average colony forming unit $\mathrm{g}^{-1}$ film \pm standard deviations.

\section{Total moisture contents of coatings}

Moisture contents of the films were measured using halogen moisture analyzer (AND MX-50, Japan). Samples weighed ( $1 \mathrm{~g}) 1$ and heated using the standard mode for gelatin $\left(200^{\circ} \mathrm{C}, 15\right.$ minutes). Measurements were made in parallel, as $\%$ moisture.

\section{Total protein content of coatings}

Total protein contents were measured according to AOAC 920.87 method (AOAC International, 2002). The amount of protein was calculated by using the correction factor for gelatin (5.3). Analyzes were performed in duplicate.

\section{Coating thickness}

A digital caliper was used to determine the thickness of coatings. Average of measurements taken at 5 different points were calculated.

Moisture loss \% during storage

To determine the moisture loss due to storage, 
coated cheese samples were weighed on 1st, 3rd and 5th days of storage using the following formula.

Moisture loss $(\%)=\frac{\text { Initial weight-final weight }}{\text { Initial wieght }} \times 100(1)$

\section{Coating solubility}

The modified method of Hoque et al., (2011), was used to determine the coating solubility. Samples were cut in sizes $1 \times 1.5 \mathrm{~cm}$ and weighed, then they were taken up into centrifuge tubes and added to $10 \mathrm{ml}$ of $0.1 \%$ ( $\mathrm{w} / \mathrm{v}$ ) sodium azide $\left(\mathrm{NaN}_{3}\right)$ solution. The prepared liquid and samples were stirred at room temperature for 24 hours at $150 \mathrm{rpm}$ on a shaker (Stuart-Orbital Shaker, China). Mixtures were then centrifuged at $4200 \mathrm{~g}$ for 10 minutes and vortexed for $1 \mathrm{~min}$. Centrifugation was repeated once more. The mixtures were poured into tared petri dishes and allowed to stand at $105^{\circ} \mathrm{C}$ for 24 hours to obtain amount of the dry insolubilized film. Finally, they were weighed and film solubility was calculated for each sample by subtracting the amount of dry insolubilized film from the total weight.

\section{Color determination}

Color measurements for coatings were measured with a Chromameter (CR-400, Konica Minolta Holdings Inc., Tokyo, Japan). Hunter L,a,b values were used as: $L^{*}$ value was for measuring darkness/lightness; while $a^{*}$ value for redness; and $b^{*}$ value for yellowness in films. Color parameters for the standard white plane were as follows: $L_{o}=95.9, a_{o}=0.2, b_{o}=2.3$. The total color change $(\Delta E)$ in $L, a, b$ values is calculated according to the following formula.

$$
\Delta E^{*}=\sqrt{\left(L-L_{o}\right)^{2}+\left(a-a_{o}\right)^{2}+\left(b-b_{o}\right)^{2}}
$$

\section{Statistical analysis}

Statistical analysis was performed using statistical software SPSS 20.0 (SPSS, Inc., Chicago, IL, USA) by one-way analysis of variance (ANOVA) $(p<0.05)$. Significance of differences between samples was tested by Duncan's New Multiple Range Test.

\section{Results and Discussion}

Microbiological growth on film coated cheese samples

Microbial growth during the storage of cheese is significant as it may cause off-flavors and decreased overall product quality, thus consequently may end up with serious product losses.

Total yeast count in coated white cheese samples after $3^{\text {rd }}$ day of coating treatment were depicted in Table 1, as no microbial growth was evident on $1^{\text {st }}$ day, whereas the number of colonies were too many to be counted on $5^{\text {th }}$ day.

Table 1. Total yeast counts (log cfu ml $\left.{ }^{-1}\right)$ on $3^{\text {rd }}$ day ${ }^{1}$ Çizelge 1. Toplam maya miktarları (log cfu ml-1) (3.gün) $)^{1}$

\begin{tabular}{|l|c|}
\hline $\begin{array}{l}\text { Sample } \\
\text { Ornek }\end{array}$ & $\begin{array}{c}\text { Total yeast } \\
\text { Toplam maya }\end{array}$ \\
\hline Soy protein with grape juice & $5.65 \pm 0.27^{\mathrm{a}}$ \\
\hline Soy protein no grape juice & $5.69 \pm 0.22^{\mathrm{a}}$ \\
\hline Whey protein with grape juice & $5.42 \pm 0.15^{\mathrm{a}}$ \\
\hline Whey protein with no grape juice & $5.53 \pm 0.16^{\mathrm{a}}$ \\
\hline Gluten protein with grape juice & $<2^{\mathrm{b}}$ \\
\hline Gluten protein with no grape juice & $<2^{\mathrm{b}}$ \\
\hline
\end{tabular}

${ }^{1}$ Data given represent the mean value \pm standard deviation of triplicate analyses. Values with different letters within the same column differ significantly $(p<0.05)$.

On the $3^{\text {rd }}$ day, soy protein coating with no grape juice addition had the highest yeast content among all samples (5.69 log cfu ml-1). According to the results no significant differences were detected between soy protein and whey protein coated cheese samples ( $p>0.05)$. Gluten film coated cheeses had no yeast content at all, probable cause of this observation was the use of ethanol in the production of gluten coatings. These coatings showed an inhibition effect on microbial growth. Grape juice addition into soy and whey protein coatings, had a slight decreasing effect on the amount of total yeast, although this effect was not statistically significant $(p>0.05)$. In contrast, some previous studies have shown more profound effects on the microbial load decrease with grape juice or grape seed extract additions (Shah et al., 2014). Similarly, total bacteria in the chicken was 4.77 
log cfu g-1 in the sample with grape extract added and $6.49 \mathrm{log} \mathrm{cfu} \mathrm{g}^{-1}$ in the control group (Abu Hafsa and Ibrahim, 2018). No mold or coliform bacteria growth were detected in coated cheese samples of after each of 1,3 and 5 days after treatment.

\section{Moisture contents of coatings}

Moisture contents of different films were depicted in Table 2 . Whey protein film with grape juice had the highest moisture content (29.6\%) and average moisture content was measured as $25.6 \pm 2.1 \%$ in different types of films. Moisture content of whey protein film with grape juice was significantly higher $(p<0.05)$ than all samples except gluten protein film with grape juice. Grape juice addition increased the moisture contents of all samples. Increased moisture content due to fruit sources incorporation into biodegradable films/coatings was common to previous literature (Hashemi et al., 2016). The moisture levels of the films were in parallel to the findings of previous studies (Ramos et al., 2013). Moreover, although difference in glycerol contents of the films in other studies has been proposed as a factor in different moisture contents measured (according to Ramos et al. (2013), increase in glycerol content from 40 to $60 \%(\mathrm{w} / \mathrm{w})$ in whey protein films caused around $3.60 \%$ increase in moisture content, extent of glycerol differences has not been a distinct factor for the moisture contents measured in present study. Glycerol addition increase the soluble solids and its hygroscopic structure increases the moisture absorption by attracting water molecules (Galus and Kadzińska, 2016).

\section{Total protein contents of coatings}

Total protein contents of coatings are given in Table 2. The highest amount of protein was measured in whey protein with grape juice (59.7 $\%)$. Average amount of protein content was determined as $52.4 \pm 5.4 \%$ for all films. Soy protein films had significantly lower amount of proteins than that of whey protein films $(p<0.05)$. Both of whey protein isolates and whey protein concentrates have been reported to contain comparatively higher amount of proteins (30-80\% (w/w) for concentrates and above $90 \%(w / w)$ for isolates) (Mulvihill and Ennis, 2003); therefore the higher amount of protein in those films was as expected.

No differences detected in film protein contents after grape juice addition, and this was expected since grapes are poor in total protein content.

\section{Coating thickness}

Thickness measurements were displayed in Table 2 . In soy protein and gluten protein coatings with grape and without grapes, thickness values were very close to each other; $(0.23-0.24 \mathrm{~mm})$ and $(0.19-0.20 \mathrm{~mm})$, respectively. The width values of whey protein films changed between 0.32 and $0.44 \mathrm{~mm}$, respectively for samples with and without grapes, being slightly higher than the rest of the film samples. Differences were statistically significant $(p<0.05)$. In coatings with grape juice, the thicknesses were slightly lower in comparison to those ones without grape juice. In literature, the increase in the moisture contents of films, has been related with the increased time for evaporation of water and consequent formation of thinner films (Anker et al., 1999).

Average thickness of all films was measured as $0.27 \pm 0.09 \mathrm{~mm}$. Thickness values measure in present study were higher than other studies in literature. In a previous study, thickness of films samples having whey protein increased due to the sorbic acid content addition as antimicrobial agent. The content of sorbic acid varied between $0.5 \%$ and $1.5 \%(\mathrm{w} / \mathrm{w})$, while the thickness values changed between $0.12 \mathrm{~mm}$ and $0.14 \mathrm{~mm}$ (Cagrı et al., 2001). Thickness differences between coatings are thought to be due to the ratio of plasticizer quantities as well as the proportions of protein powders in film formation (Ramos et al., 2013). Increase in the protein concentration, may be related with the increase in thickness of the coating as high protein concentrations the enhanced protein gelling in coating materials produced (Anker et al., 1999). Moreover, main 
characteristics of the coating materials including solubility, density, viscosity, and surface tension are also effective on barrier, mechanical and optical properties of the coatings (Costa et al., 2018). Lower thickness of films has been proposed as a positive factor for films to improve the over-all desirability of final packaged products, specifically for edible films (Khanzadi et al., 2015).

Table 2. Some properties of protein coatings ${ }^{1}$

Çizelge 2. Protein kaplamaların bazı özellikleri

\begin{tabular}{|c|c|c|c|}
\hline Sample & $\begin{array}{l}\text { Moisture content, \% } \\
\text { \% Nem içeriği }\end{array}$ & $\begin{array}{l}\text { Protein content, \% } \\
\% \text { Protein içeriği }\end{array}$ & Thickness (mm) \\
\hline Örnek & & & Kalınlık (mm) \\
\hline Soy protein with grape juice & $25.3 \pm 0.0^{b}$ & $47.6 \pm 0.8^{b}$ & $0.23 \pm 0.03^{c}$ \\
\hline Soy protein with no grape juice & $24.6 \pm 0.2^{b}$ & $44.3 \pm 2.5^{b}$ & $0.24 \pm 0.06^{c}$ \\
\hline Whey protein with grape juice & $29.6 \pm 0.1^{\mathrm{a}}$ & $59.7 \pm 3.9^{a}$ & $0.32 \pm 0.06^{b}$ \\
\hline Whey protein with no grape juice & $24.1 \pm 0.2^{\mathrm{b}}$ & $57.9 \pm 0.1^{\mathrm{a}}$ & $0.44 \pm 0.08^{a}$ \\
\hline Gluten protein with grape juice & $26.0 \pm 0.0^{\mathrm{ab}}$ & $52.5 \pm 2.9^{a b}$ & $0.19 \pm 0.01^{c}$ \\
\hline Gluten protein with no grape juice & $24.1 \pm 0.1^{b}$ & $52.5 \pm 2.2^{\mathrm{ab}}$ & $0.20 \pm 0.03^{c}$ \\
\hline Average & $25.6 \pm 2.1$ & $52.4 \pm 5.4$ & $0.27 \pm 0.09$ \\
\hline
\end{tabular}

${ }^{1}$ Data given represent the mean value \pm standard deviation of duplicate analyses. Values with different letters within the same column differ significantly $(p<0.05)$.

\section{Moisture loss \% during storage}

Moisture loss in cheese might be considered as a problem increasing the cheese hardness and leading to undesired organoleptic properties (Costa et al., 2018). During storage, changes in sample moisture contents was measured by monitoring their weight losses. According to the findings, the greatest part of moisture loss was measured in the first day, right after packaging for all samples. Values are given in Table 3 . The changes in sample weights were statistically insignificant after the $1^{\text {st }}$ day of storage $(p>0.05)$. However, in samples with no grape juice, weight loss was measured between the $1^{\text {st }}$ and $3^{\text {rd }}$ days was slightly higher in samples with soy protein, than the other two samples. For the samples containing grape juice, on the other hand, the moisture loss from the $1^{\text {st }}$ to $3^{\text {rd }}$ day was higher than the no grape juice added counterparts, for all types of protein coatings. The highest decrease was detected in gluten coated samples.

In quite a recent study, it has been stated that in fruit samples such as coated apples, moisture loss \% levels were around 20 and $40 \%$, respectively for whey protein or soy protein isolate coatings after 10 days of storage (Marquez et al., 2017). In the same study, maximum weight loss was reached only after 2 days of storage in soy protein film coated carrot samples and has been related with the intrinsic hydrophilic nature of soy protein films (Rhim, 2004) and therefore they suggested using enzymatically reticulated films as having better protection properties (Marquez et al., 2017). Protein coatings have some similarities to protein gels, being viscoelastic materials those depicting characteristics of both solids and liquids. Therefore, interaction of different protein sources and small molecules, including water, plasticizers, and other additives existing in the coating material matrix, affect the mechanical properties of the protein coatings (Chen, 1995). Moreover, $\mathrm{pH}$, pressure and heat also have been reported to have an impact of the gel strength. Value of coating solution $\mathrm{pH}$, influences both the mechanical and barrier properties. The isoelectric point of the protein (that is $\mathrm{pH} 4.5$ for soy protein and 7.5 for wheat gluten) has an important role on water vapor permeation and the oxygen permeation of the films as they have their maxima at the isoelectric point. In present study, average $\mathrm{pH}$ values were measured as 11.2 in soy protein, 11.1 in whey protein and as 10.0 in gluten coating solutions. Therefore, alkaline conditions over their isoelectric points might also have been effective the higher moisture loss values measured (Zink et al, 2016). 
Table 3. \% Moisture loss in coatings during storage ${ }^{1,2}$

Çizelge 3. Depolama sırasında kaplamalardaki \% nem kaybı

\begin{tabular}{|c|c|c|c|}
\hline \multicolumn{4}{|c|}{$\begin{array}{c}\text { Coatings without grape juice } \\
\text { Üzüm suyu eklenmemiş kaplamalar }\end{array}$} \\
\hline $\begin{array}{l}\text { Days of storage } \\
\text { Depolama günü }\end{array}$ & $\begin{array}{l}\text { Soy protein } \\
\text { Soya proteini }\end{array}$ & $\begin{array}{l}\text { Whey protein } \\
\text { Peynir altı suyu proteini }\end{array}$ & $\begin{array}{l}\text { Gluten } \\
\text { Gluten }\end{array}$ \\
\hline Day 0 & $100.0 \%^{a}$ & $100.0 \%^{a}$ & $100.0 \%^{a}$ \\
\hline Day 1 & $45.6 \%^{b}(-54.4 \%)$ & $44.2 \%^{b}(-55.8 \%)$ & $44.3 \%^{b}(-55.7 \%)$ \\
\hline Day 3 & $40.6 \%^{b}(-5.0 \%)$ & $43.6 \%^{\mathrm{b}}(-0.6 \%)$ & $42.9 \%{ }^{b}(-0.4 \%)$ \\
\hline Day 5 & $39.8 \%{ }^{b}(-0.8 \%)$ & $43.4 \%$ b $(-0.2 \%)$ & $42.5 \%{ }^{b}(-0.4 \%)$ \\
\hline \multicolumn{4}{|c|}{$\begin{array}{c}\text { Coatings with grape juice } \\
\text { Üzüm suyu eklenmiş kaplamalar }\end{array}$} \\
\hline $\begin{array}{l}\text { Days of storage } \\
\text { Depolama günü }\end{array}$ & $\begin{array}{l}\text { Soy protein } \\
\text { Soya proteini }\end{array}$ & $\begin{array}{l}\text { Whey protein film } \\
\text { Peynir altı suyu proteini }\end{array}$ & $\begin{array}{l}\text { Gluten film } \\
\text { Gluten }\end{array}$ \\
\hline Day 0 & $100.0 \%^{a}$ & $100.0 \%^{a}$ & $100.0 \%^{a}$ \\
\hline Day 1 & $46.1 \%{ }^{b}(-53.9 \%)$ & $47.8 \%{ }^{b}(-52.2 \%)$ & $45.1 \%^{b}(-54.9 \%)$ \\
\hline Day 3 & $42.6 \%^{b}(-3.5 \%)$ & $44.0 \%^{\mathrm{b}}(-3.8 \%)$ & $43.5 \%^{b}(-11.4 \%)$ \\
\hline Day 5 & $42.3 \%^{b}(-0.3 \%)$ & $43.6 \%^{b}(-0.4 \%)$ & $43.3 \%^{b}(-0.2 \%)$ \\
\hline
\end{tabular}

${ }^{1}$ Data given represent the mean value \pm standard deviation of triplicate analyses. Values with different letters within the same column differ significantly $(p<0.05)$.

2 Data in parenthesis indicate the change \% in moisture loss, during successive days

In a previous study in literature, Sarığlu and Öner (2006) measured the weight loss during storage of kaşar cheese on days of 1, 7, 30, 60 and 90 that was coated with a sodium caseinatebased film including plasticizer as sorbitol. A significant part of the weight disappeared at $10 \%$ on the 7 th day and $5 \%$ on the 30th day.

\section{Coating solubility}

Solubility of coatings for soy protein, whey protein and gluten protein-samples were depicted Table 4 as amount of solved coating (g) and $\%$ coating solubility. The solubility values of soy and whey protein coatings were lower in comparison to gluten coatings. Grape juice seemed to increase the solubility values measured and more remarkable effects were notified particularly in soy protein $(8.6 \%$ increase) and whey protein based films (16.4\% increase), in comparison to gluten based films (1.5\% increase). Lower solubility values are proposed as desirable for biodegradable films therefore the reduction in solubility measured after addition of grape juices into the films was in parallel to the previous results provided after addition of walnut oils (Galus and Kadzińska, 2016).

Table 4. Amount of solved film (g) and film solubility \% Çizelge 4. Çözünmüş film miktarı $(g)$ ve \% film çözünürlüğü

\begin{tabular}{|l|c|c|}
\hline $\begin{array}{l}\text { Sample } \\
\text { Örnek }\end{array}$ & $\begin{array}{c}\text { Amount of solved coating (g) } \\
\text { Çözünmüş kaplama miktarı }\end{array}$ & $\begin{array}{c}\text { Coating solubility, \% } \\
\text { \% Kaplama çözünürlüğü }\end{array}$ \\
\hline Soy protein with grape juice & 0.017 & 40.3 \\
\hline Soy protein with no grape juice & 0.012 & 31.7 \\
\hline Whey protein with grape juice & 0.017 & 48.9 \\
\hline Whey protein with no grape juice & 0.005 & 32.5 \\
\hline Gluten protein with grape juice & 0.025 & 60.4 \\
\hline Gluten protein with no grape juice & 0.019 & 58.9 \\
\hline
\end{tabular}

In previous studies conducted, solubility values were measured as $35.1 \%$ in films having $5 \%$ soy protein isolate (Kunte et al.; 1997) and as $30 \%$ in films having whey isolate (Perez-Gago et al., 1999). Yoshida and Antunes (2004) studied the solubility of whey protein films at different $\mathrm{pHs}$ (at different $\mathrm{pH}$ values of 5, 6.7 and 9), when the glycerol was used as plasticizer. According to their results, it was found that solubility decreased as $\mathrm{pH}$ alkalinity approached. As another example, the $\mathrm{pH}$ range from 4.5 to 7 has been reported for the maximum soy protein solubility results (Zink 
et al., 2016). In present study, average pH values were measured as 11.2 in soy protein based film solutions, 11.1 in whey protein based film solutions and as 10.0 in gluten protein based film solutions. Therefore in the similar manner with the previous literature (Yoshida and Antunes, 2004); present solubility results were lower because of the high alkalinity.

It is generally necessary to heat the proteins to certain temperatures for gel formation in films. For whey proteins, for example, when the temperature is between $70-90^{\circ} \mathrm{C}$ and between 560 minutes, the maximum performance is obtained (Barbut and Foegeding, 1993; Bryant and McClements, 1998). Isoelectric point is also another factor on protein gel strength (Zink et al., 2016).

With the heat treatment, the degree of protein denaturation and unfolding increases, and protein-protein cross-linking is affected. Moreover, high temperature application causes proteins to irreversibly aggregate and eventually form gel networks. This leads to different inter and intramolecular hydrophobic and electrostatic interactions as well as hydrogen and disulfide bonds due to the presence of cysteine residues. All these changes therefore affect the solubility of the protein films (Perez-Gago and Krochta, 2001). Generally, heat treatment during film formation procedure has been reported as a factor to decrease the solubility of the films (Rhim et al., 2000).

\section{Color determination}

For color measurements; $L, a, b$ values are given together with $\Delta \mathrm{E}$ values in Table 5. According to the results, there was no significant difference in the lightness of solid films ( $p>0.05$ ) and all films can be considered as moderately light, with only one exception; soy protein with no grape juice was slightly lighter in comparison to other films. According to a previous study in literature, the higher amount of yellow pigments in wheat may be the possible cause of less lightness in wheat in comparison to other protein sources (Evlice and Özkaya, 2011).

However, there was significant differences among both of $a$ and $b$ values $(p<0.05)$ of different film samples. Soy protein films had significantly higher values for both of redness (a) and yellowness (b) measurements $(p<0.05)$. Therefore, yellowness and redness were significantly different in comparison to other films. Difference in soy protein film color was also detectable visually.

It may be seen that addition of grape juice into the films had no significant effects in comparison to their no grape added counterparts, so it might be said that the lightness stayed fairly constant after grape juice addition. One possible reason might be the relatively lower concentration of the juices because grape extracts are important contributors to color that affects the color measurements significantly (Tacer-Caba et al., 2016).

Table 5. Color ( $L, a, b)$ values and total color change $(\triangle E)$ for film samples ${ }^{1}$

Çizelge 5. Film örneklerinde renk değerleri $(L, a, b)$ ve toplam renk değisimi $(\Delta E)$

\begin{tabular}{|c|c|c|c|c|}
\hline & $\begin{array}{l}L \\
L\end{array}$ & $\begin{array}{l}a \\
a\end{array}$ & $\begin{array}{l}\mathrm{b} \\
b\end{array}$ & $\begin{array}{l}\Delta \mathrm{E} \text { for films } \\
\text { Filmler için } \Delta E\end{array}$ \\
\hline Soy protein film with grape juice & $52.2 \pm 1.3^{a}$ & $2.3 \pm 0.2^{\mathrm{a}}$ & $18.9 \pm 4.1^{\mathrm{a}}$ & $47.0 \pm 2.6^{\mathrm{ab}}$ \\
\hline Soy protein with no grape juice & $47.9 \pm 0.2^{b}$ & $2.5 \pm 0.2^{\mathrm{a}}$ & $20.8 \pm 0.8^{a}$ & $51.6 \pm 0.2^{a}$ \\
\hline Whey protein film with grape juice & $50.5 \pm 3.3^{a b}$ & $0.6 \pm 0.0^{b}$ & $2.6 \pm 0.6^{b}$ & $45.4 \pm 3.4^{\mathrm{ab}}$ \\
\hline Whey protein film with no grape juice & $54.9 \pm 1.2^{\mathrm{a}}$ & $0.2 \pm 0.1^{c}$ & $2.5 \pm 0.4^{b}$ & $41.0 \pm 1.2^{b}$ \\
\hline Gluten protein film with grape juice & $52.0 \pm 3.2^{a}$ & $-0.8 \pm 0.0^{c}$ & $6.5 \pm 0.8^{b}$ & $44.1 \pm 3.2^{\mathrm{b}}$ \\
\hline Gluten protein film with no grape juice & $53.5 \pm 1.1^{\mathrm{a}}$ & $-0.7 \pm 0.1^{c}$ & $6.5 \pm 0.7^{b}$ & $42.6 \pm 1.2^{b}$ \\
\hline
\end{tabular}

${ }^{1}$ Data given represent the mean value \pm standard deviation of duplicate analyses. Values with different letters within the same column differ significantly $(p<0.05)$.

According to the findings of $\Delta \mathrm{E}$ values; soy protein film had slightly higher than the other two protein sources. Although, grape juices addition into the films was an increasing factor for color 
difference, one exception was soy protein films in which grape juice addition was found to lower the extent of color change. Changes in $\Delta E$ values are thought to be due to $\mathrm{pH}$ and film thickness. The thickness of the film is between 0.19-0.44 mm. As a general visual evaluation, all coatings formed in the present work had the transparent color and solid, firm and elastic structure.

\section{Conclusion}

In this study, different protein coatings were analyzed for their performance as white cheese packaging. According to the findings of the study, whey protein coating with grape juice seemed superior to the other treatments by sustaining the lowest microbiological load and moisture loss in cheese samples, in addition to showing the least color change and moderate solubility as a coating material. Grape juice addition into the protein coatings was beneficial, however higher concentrations might work better in future applications.

\section{Acknowledgement}

This study has been conducted as a postgraduate study at Istanbul Aydin University Graduate School of Science, Engineering and Technology, Food Engineering MSc. Program.

\section{References}

Abu Hafsa, S. H., \& Ibrahim, S. A. (2018). Effect of dietary polyphenol-rich grape seed on growth performance, antioxidant capacity and ileal microflora in broiler chicks. Journal of Animal Physiology and Animal Nutrition, 102 (1), 268-275.

Akbari, Z., Ghomashchi, T., \& Moghadam, S. (2007). Improvement in food packaging industry with biobased nanocomposites. International Journal of Food Engineering, 3(4), 1-24.

Akcan, T., Estevez, M., \& Serdaroglu, M. (2017). Antioxidant protection of cooked meatballs during frozen storage by whey protein edible films with phytochemicals from Laurus nobilis L and Salvia officinalis. LWT Food Science and Technology, 77, 323-331.

Anker, M., Stading, M., \& Hermansson, A. (1999). Effects of $\mathrm{pH}$ and the gel state on the mechanical properties, moisture contents, and glass transition temperatures of whey protein films. Journal of Agricultural and Food Chemistry, 47, 1878-1886.

Association of Official Analytical Chemists (AOAC). (2002). Official methods of analysis. Virginia, USA: Association of Official Analytical Chemists.
Barbut, S., \& Foegeding, E. A. (1993). Ca ${ }^{2+-}$ induced gelation of pre-heated whey protein isolate. Journal of Food Science, 58(4), 867-8.

Bryant, C. M., \& McClements, D. J. (1998). Molecular bases of protein functionality with special consideration of cold-set gels derived from heat-denatured whey. Trends in Food Science and Technology, 9(4), 143151.

Cagrı, A., Ustunol, Z., \& Ryster, E. T. (2001). Antimicrobial, mechanical and moisture barrier properties of low whey protein-based edible films containing aminobenzoic or sorbic acids. Journal of Food Science, 66(6), 865-870.

Chen, H. (1995). Functional properties and applications of edible films made of milk proteins. Journal of Dairy Science, 78, 2563-2583.

Costa, M. J., Maciel, L. C., Teixeira, J. A., Vicente, A. A., \& Cerqueira, M. A. (2018). Use of edible films and coatings in cheese preservation: Opportunities and challenges. Food Research International, 107, 84-92.

De Lima Marques, J., Funck, G. D., Da Silva Dannenberg, G., Dos Santos Cruxen, C. E., El Halal, S. L. M., \& Dias, A. R. G. (2017). Bacteriocin-like substances of Lactobacillus curvatus P99: characterization and application in biodegradable films for control of Listeria monocytogenes in cheese. Food Microbiology, 63, 159-163.

Evlice, A. K., \& Özkaya, H. (2011). Makarnalık buğdayda farklı cihazlarla saptanan renk değerinin kalite yönünden değerlendirilmesi. Tarla Bitkileri Merkez Araştırma Enstitüsü Dergisi, 20(2), 33-40.

Galus, S., \& Kadzińska, J. (2016). Whey protein edible films modified with almond and walnut oils. Food Hydrocolloids, 52, 78-86.

Gennadios, A. (2002). Protein-based films and coatings. Boca Raton, FL: CRC Press.

Gontard, N., Guilbert, S., \& Cuq, J. L. (1993). Water and glycerol as plasticizers affect mechanical and water vapor barrier properties of an edible wheat gluten film. Journal of Food Science, 58, 201-211.

Gontard, N., \& Guillaume, C. (2010). Packaging and the shelf life of fruits and vegetables. In: Food Packaging and Shelf Life. A Practical Guide. (Ed) Robertson, G. L., Boca Raton, FL: CRC Press, 297-315 pp.

Gounga, M. E., Xu, S. Y., \& Wang, Z. (2007). Whey protein isolate-based edible films as affected by protein concentration, glycerol ratio and pullulan addition in film formation. Journal of Food Engineering, 83, 521530.

Guilbert, S. (1986). Food packaging and preservation. In: Theory and Practice in Technology and Application of Edible Protective Films. London, UK: Elsevier Applied Science Publishing Co., 371-394 pp.

Guimarães, A., Abrunhosa, L., Pastrana, L. M., \& Cerqueira, M. A. (2018). Edible films and coatings as carriers of living microorganisms: A new strategy towards biopreservation and healthier foods. Comprehensive Reviews in Food Science and Food Safety, 17(3), 594614.

Gurdian, C., Chouljenko, A., Solval, K. M., Boeneke, C., King, J. M., \& Sathivel, S. (2017). Application of edible films containing oregano (Origanum vulgare) essential oil on Queso Blanco cheese prepared with flaxseed 
(Linum usitatissimum) Oil. Journal of Food Science, 82 (6), 1395-1401.

Gutierrez, J., Barry-Ryan, C., \& Bourke, P. (2009). Antimicrobial activity of plant essential oils using food model media: efficacy, synergistic potential and interactions with food components. Food Microbiology, 26 (2), 142-150.

Hashemi, S. M. B., Zahabi, N., Rezaee, Z., Maherani, Z., Boghori, P., \& Keshavarz, Z. (2016). Evaluation of a starch-based edible film as carrier of Adiantum capillus-veneris extract to improve the shelf life of fresh-cut pears. Journal of Food Safety, 36 (3), 291298.

Hoque, M.S., Benjakul, S., \& Prodpran, T. (2011). Properties of film from cuttlefish (Sepia pharaonis) skin gelatin incorporated with cinnamon, clove and star anise extracts. Food Hydrocolloids, 25 (5), 1085-1097.

ISO 7954 (1988). General Guidance for Enumeration of Yeasts and Moulds. Colony Count Technique at $25^{\circ} \mathrm{C}$. International Standards Organization, Geneva, Switzerland.

Karagözlü, N., \& Karagözlü, C. (2016). Carnobacterium maltaromaticum ve peynir olgunlaşmasında önemi. Harran Tarım ve Gıda Bilimleri Dergisi, 20(1), 62-70

Karagul-Yuceer, Y., Isleten, M., \& Uysal-Pala, C. (2007). Sensory characteristics of Ezine cheese. Journal of Sensory Studies, 22 (1), 49-65.

Kaya, S., \& Kaya, A. (2000). Microwave drying effects on properties of whey protein isolate edible films. Journal of Food Engineering, 43 (2), 91-96.

Kayserilioğlu, B. Ş., Bakır, U., Yılmaz, L., \& Akkaş, N. (2003). Drying temperature and relative humidity effects on wheat gluten film properties. Journal of Agricultural and Food Chemistry, 51, 964-968.

Khanzadi, M., Jafari, S. M., Mirzaei, H., Chegini, F. K., Maghsoudlou, Y., \& Dehnad, D. (2015). Physical and mechanical properties in biodegradable films of whey protein concentrate-pullulan by application of beeswax. Carbohydrate Polymers, 118, 24-29.

Khwaldia, K., Perez, C., Banon, S., Desobry, S., \& Hardy, J. (2004). Milk proteins for edible films and coatings. Food Science and Nutrition, 44, 239-251.

Kinsella, J.E., \& Whitehead, D.M., (1989). Proteins in whey: Chemical, physical and functional properties. Advanced Food and Nutrition, 33, 343-348.

Kunte, L.A., Gennadios, A., Cuppett, S.L., Hanna, M.A., \& Weller, C.L. (1997). Cast films from soy protein isolates and fractions. American Association of Cereal Chemists, 74 (2), 115-118.

Liu, K. (2004). Soybean as functional foods and ingredients. Champaign, IL: AOCS Publishing.

Marquez, G. R., Di Pierro, P., Mariniello, L., Esposito, M., Giosafatto, C. V., \& Porta, R. (2017). Fresh-cut fruit and vegetable coatings by transglutaminasecrosslinked whey protein/pectin edible films. LWTFood Science and Technology, 75, 124-130.

Mariniello, L., Pierro, P., Esposito, C., Sorrentino, A., Masi, P., \& Porta, R. (2003). Preparation and mechanical properties of edible pectin-soy flour films obtained in the absence or presence of transglutaminase. Journal of Biotechnology, 102, 191-198.

McHugh, T. H., Aujard, J. F., \& Krochta, J. M. (1994). Plasticized whey protein edible films: water vapor permeability properties. Journal of Food Science, 59, 416-419.

Mulvihill, D. M., \& Ennis, M. P. (2003). Functional milk proteins: production and utilisation. In: Advanced Dairy Chemistry, vol. 1, Part B. (Ed) Fox, P. F., McSweeney, P. L. H., Boston, MA: Springer, 11761228 pp.

Nie, X., Gong, Y., Wang, N., \& Meng, X. (2015). Preparation and characterization of edible myofibrillar proteinbased film incorporated with grape seed procyanidins and green tea polyphenol. LWT-Food Science and Technology, 64 (2), 1042-1046.

Öner, T., (2006). Soya Sektör Raporu. İstatistik Şubesi.

Ozdemir, M., \& Floros, J. D. (2008). Optimization of edible whey protein films containing preservatives for mechanical and optical properties. Journal of Food Engineering, 84 (1), 116-123.

Pochat-Bohatier, C., Sanchez, J., \& Gontard, N. (2005). Influence of relative humidity on carbon dioxide sorption in wheat gluten films. Journal of Food Engineering, 77, 983-991.

Perez-Gago, M. B., Nadaud, P., \& Krochta, J. M. (1999). Water vapor permeability, solubility, and tensile properties of heat-denatured versus native whey protein films. Journal of Food Science, 64 (6), 10341037.

Perez-Gago, M. B., \& Krochta, J. M. (2001). Denaturation time and temperature effects on solubility, tensile properties, and oxygen permeability of whey protein edible films. Journal of Food Science, 66 (5), 705-710.

Ramos, Ó. L., Reinas, I., Silva, S. I., Fernandes, J. C., Cerqueira, M. A., Pereira, R. N., Vicente, A. A., Pocas, M. F., Pintado, M. E., \& Malcata, F. X. (2013). Effect of whey protein purity and glycerol content upon physical properties of edible films manufactured therefrom. Food Hydrocolloids, 30 (1), 110-122.

Rhim, J. W. (2004). Increase in water vapor barrier properties of biopolymer-based edible films and coatings by compositing lipid materials. Food Science and Biotechnology, 13, 528-535.

Riaz, M. N. (2001). Uses and benefits of soy fiber. Cereal Foods World, 46, 98-100.

Sarığlu, T., \& Öner, Z. (2006). Yenilebilir filmin kaşar peynir kaplanmasında kullanılma olanakları ve peynir kalitesi üzerine etkileri. Gıda, 31 (1), 3-10.

Shah, M. A., Bosco, S. J. D., \& Mir, S. A. (2014). Plant extracts as natural antioxidants in meat and meat products. Meat Science, 98 (1), 21-33.

Tacer-Caba, Z., Nilufer-Erdil, D., Boyacioglu, M. H., \& Ng, P. K. W. (2016). Effect of wheat protein isolate addition on the quality of grape powder added wheat flour extrudates. Quality Assurance and Safety of Crops \& Foods, 8 (2), 215-230.

Tanada-Palmu, P. S., \& Grosso, C. R. (2005). Effect of edible wheat gluten-based films and coatings on refrigerated strawberry (Fragaria ananassa) quality. Postharvest Biology and Technology, 36 (2), 199-208.

Temiz, H., \& Yeşilsu, A. F. (2006). Bitkisel protein kaynaklı yenilebilir film ve kaplamalar. Gıda Teknolojisi Dergisi, 2, 41-50.

Varzokas, T., \& Tzia, V. (2016). Handbook of food processing: Food preservation. New York, NY: CRC Press. 
Yoshida, C. M. P., \& Antunes, A. J. (2004). Characterization of whey protein emulsion films. Brazilian Journal of Chemical Engineering, 21 (2), 247-252.

Zhong, Y., Cavender, G., \& Zhao, Y. (2014). Investigation of different coating application methods on the performance of edible coatings on Mozzarella cheese. LWT-Food Science and Technology, 56(1), 1-8. Zink, J., Wyrobnik, T., Prinz, T., \& Schmid, M. (2016). Physical, chemical and biochemical modifications of protein-based films and coatings: an extensive review. International Journal of Molecular Sciences, 17,1376 . 